\title{
Effects of Particle Size and Composite Composition of Carbon Microparticles as Reinforcement Components on Resin-Based Brake Pad Performance
}

DOI:10.36909/jer.ASSEEE.16039

Asep Bayu Dani Nandiyanto*, Alya Chairunnisa Tahira, Siti Nur Hofifah, Silmi Ridwan Putri, Gabriela Chelvina Santiuly Girsang

Departemen Pendidikan Kimia, Universitas Pendidikan Indonesia, Jl. Dr. Setiabudhi No. 229, Bandung, 40154, Indonesia.

*Email: nandiyanto@upi.edu; Corresponding Author.

\section{ABSTRACT}

This study aims to investigate the effect of particle size and composition of bamboo and clove leaves as reinforcement components on resin-based brake pad performance. Bamboo fibers contain cellulose and lignin, making them better mechanical properties compared to glass fibers. Clove leaves due to their containment of oil components can be used, playing roles in binding bamboo with resin material. In short, experiments were done by involving polymerization of polyester resin as an adhesive with methyl ethyl ketone peroxide (MEKP) at room temperature. The composition of polyester/MEKP/reinforcing components was fixed at a mass ratio of 10/1/1.76 and the particle size of the reinforcing components were 582 and 250 $\mu \mathrm{m}$. Reinforcing components were mixed carbonized bamboo fiber and dried clove leaves with a ratio of $4 / 1 ; 7 / 1$; and $10 / 1$. The results showed that smaller particles has better mechanical properties, and the more amount of bamboo particles give positive impacts on the material hardness. The best hardness value (reaching $\left.24 \mathrm{~N} / \mathrm{cm}^{2}\right)$ and smallest pore volume $\left(0.0213 \mathrm{~cm}^{3}\right)$ were obtained when using the ratio of 10:1. While the smallest weight loss of mass at the rate of $0.1225 \mathrm{~g} / \mathrm{min}$ was obtained by the ratio of $7 / 1$. The largest friction coefficient and lowest wear rate were obtained by $4 / 1$ with a value of 0.1108 and $1.08 \mathrm{~g} / \mathrm{s} \mathrm{mm}^{2}$, respectively. This study demonstrates the use of biomass waste such as bamboo fiber and dried clove leaves as an alternative to asbestos and reduces the abundant waste of bamboo powder and dried clove leaves in Indonesia.

Keywords: brake pad, composites, non-asbestos, polyester resin, biomass

\section{INTRODUCTION}

Brake pad contains a friction component that is bonded on the surface of the brake component 
for facing and interacting with the brake disk. Brake pad generally consists of asbestos fibers (Aigbodon et al., 2010). The brake pad is also supported by specific components for improving brake pad performance and giving additional functions, including friction properties at low and high temperatures, reducing noise, increasing brake pad life, increasing strength, and reducing porosity. Changes in supporting components in the brake pad can affect the quality, chemical, mechanical and physical properties of the final brake pad (Abutu et al., 2018; Bagaskara, Widodo, and Pramono, 2019). The brake pad also contains a binder, reinforcing materials, and filler (Bagaskara, Widodo, and Pramono, 2019; Ma et al., 2012). Binder, which has a role in binding components, can be from polyester resin, epoxy resin, and phenolic resin. Reinforcing material serves to increase the coefficient of friction and increase the mechanical strength of the material, which can be from nylon, copper-zinc, aluminum, carbon, and rock wool or natural fibers such as bamboo, hemp, coconut fibers, and various other natural materials (Bagaskara, Widodo, and Pramono, 2019).

Recently, brake pad utilizes asbestos fiber, which is not environmentally friendly, causing problems in respiratory disease (Aminur, Hasbi, and Gunawan, 2015). For this reason, there is a need for finding alternative materials of asbestos fiber. The differences from the previous studies were most of the natural fibers are not carbonized. The materials with more carbon fiber will make higher density and hardness. This happens because of the possibility of the carbon fiber to attract metals around them to assemble and the material resulted more compact and hard when the curing process happens (Kuntari et al., 2013). Several materials are presented in Table 1.

Here, this study aimed to investigate the effects of particle size and composition of bamboo and clove leaves as reinforcement components on resin-based brake pad performance. Bamboo fibers were used as an alternative to asbestos in brake pad friction materials because they have low density and good mechanical properties compared to glass fibers (Ma et al., 2012). Among other natural fiber plants, bamboo is one of the fastest-growing grass plants ( $\mathrm{Li}$ et al., 1998), making it abundant in many countries and useful as a renewable resource (Thwe and Liao, 2003). In general, the chemical constituents of bamboo are 50-70\% of holocellulose, 30\% of pentosan, and 20-25\% of lignin (Dwivedi, Ghost, and Chan, 2009). Unfortunately, although the impact and tensile strength of bamboo are categorized as excellent, bamboo fiber is used limitedly in the preparation of low-grade structural materials, such as furniture and light car parts (Costa, Loiola, Monteiro, 2010). Other supporting materials are clove, which is abundant in tropical countries (Tagora and Rinaldy, 2012; 
Suarya, 2007). Clove leaves contain oil that has the basic constituent of eugenol (2-methoxy4-allylphenol) (Leopold et al., 2006). Clove leaves due to their containment of oil components can be used, playing roles in binding bamboo with resin material.

Table 1. Comparison of the developed brake pads using natural fiber in previous studies.

\begin{tabular}{|c|c|c|c|c|}
\hline $\begin{array}{l}\text { Agricultural } \\
\text { waste }\end{array}$ & Supporting Material & Result of the Research & $\begin{array}{l}\text { The difference } \\
\text { with this study }\end{array}$ & Ref. \\
\hline \multirow[t]{2}{*}{ Bamboo fiber } & $\begin{array}{l}\text { Carbon black, } \mathrm{Al}_{2} \mathrm{O}_{3} \text {, } \\
\text { vermiculite powder, }\end{array}$ & $\begin{array}{l}\text { The increase in bamboo fiber in the } \\
\text { brake pad was } 12 \mathrm{wt} \% \text {, the friction }\end{array}$ & $\begin{array}{l}\text { Treating bamboo } \\
\text { fiber with } \\
\mathrm{NaOH}, \text {. }\end{array}$ & $\begin{array}{l}\text { (Ma et al., } \\
\text { 2012) }\end{array}$ \\
\hline & $\begin{array}{l}\mathrm{BaSO}_{4}, \text { foam iron, } \\
\text { petroleum coke, } \mathrm{Sb}_{2} \mathrm{~S}_{3} \text {, } \\
\text { friction } \\
\text { graphite, zinc stearate, } \\
\text { glass fiber, phenolic } \\
\text { resin. }\end{array}$ & $\begin{array}{l}\text { coefficient increased and the wear } \\
\text { rate decreased when the bamboo } \\
\text { fiber content was less than } 3 \mathrm{wt} \%\end{array}$ & $\begin{array}{l}\text { different } \\
\text { adhesive used }\end{array}$ & \\
\hline $\begin{array}{l}\text { Mango seed's } \\
\text { skin, brass } \\
\text { powder }\end{array}$ & $\mathrm{MgO}$, epoxy resin. & $\begin{array}{l}\text { The variance with wear rate in the } \\
\text { value of } 3.1 \times 10^{-7} \mathrm{~mm}^{2} / \mathrm{kg} \text { and the } \\
\text { best hardness in the value of } \\
214,38 \mathrm{~kg} / \mathrm{mm}^{2} \text { has the closest } \\
\text { value with KEV-2700. }\end{array}$ & $\begin{array}{l}\text { Different } \\
\text { biomass and } \\
\text { adhesive used }\end{array}$ & $\begin{array}{l}\text { (Bagaskara, } \\
\text { Widodo, } \\
\text { and } \\
\text { Pramono, } \\
\text { 2019) }\end{array}$ \\
\hline $\begin{array}{l}\text { Carbonized } \\
\text { sawdust wood }\end{array}$ & epoxy resin & $\begin{array}{l}\text { The largest friction coefficient in } \\
\text { the number of } 0.445 \text { and lowest } \\
\text { wear rate in the number of } 4.13 \\
\mathrm{~mm}^{2} / \mathrm{kg} \text {. }\end{array}$ & $\begin{array}{l}\text { Different } \\
\text { biomass and } \\
\text { adhesive used }\end{array}$ & $\begin{array}{l}\text { (Puja, } \\
\text { 2010) }\end{array}$ \\
\hline Cashew powder & 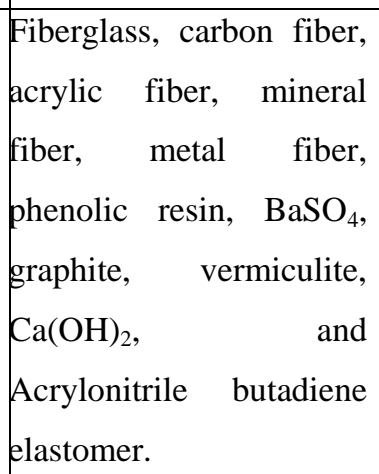 & $\begin{array}{l}\text { The largest hardness value was } \\
84.50 \text { HRR, the largest friction } \\
\text { coefficient } 0.14 \text {, and the lowest } \\
\text { rate in the value of } 0.30 \text {. }\end{array}$ & $\begin{array}{l}\text { Different } \\
\text { biomass and } \\
\text { adhesive used }\end{array}$ & $\begin{array}{l}\text { (Suhardjo } \\
\text { et al. 2013) }\end{array}$ \\
\hline Bamboo fiber & $\mathrm{MgO}$ and epoxy resin. & $\begin{array}{l}\text { The Average wear rate in the value } \\
\text { of } 1.6596 \mathrm{~g} / \mathrm{mm}^{2} . \mathrm{s} \text { and the average } \\
\text { Rockwell hardness value is } 83.23 \\
\text { HRR. }\end{array}$ & $\begin{array}{l}\text { Uncarbonized } \\
\text { bamboo fiber } \\
\text { and different } \\
\text { adhesive used. }\end{array}$ & $\begin{array}{l}\text { (Sukrawan, } \\
\text { Hamdani, } \\
\text { and } \\
\text { Mardani, } \\
\text { 2019) }\end{array}$ \\
\hline $\begin{array}{l}\text { Cocoa bean } \\
\text { shells }\end{array}$ & $\begin{array}{l}\text { Iron oxide, epoxy } \\
\text { resin+hardener, } \mathrm{CaCO}_{3} \text {, }\end{array}$ & $\begin{array}{l}\text { The average friction coefficient } \\
\text { was } 0.34 \mu \text {. The average hardness }\end{array}$ & $\begin{array}{l}\text { Different } \\
\text { biomass and }\end{array}$ & $\begin{array}{l}\text { (Olabisi, } \\
\text { Adam, and }\end{array}$ \\
\hline
\end{tabular}




\begin{tabular}{|c|c|c|c|c|}
\hline & $\begin{array}{l}\text { silica, and powdered } \\
\text { graphite. }\end{array}$ & $\begin{array}{l}\text { value in the number of } 111.37 \\
\text { Mpa. The average wear rate in the } \\
\text { value } 2.02 \times 10^{-6} \mathrm{~g} / \mathrm{m} \text { and the } \\
\text { average Modulus compressive } \\
\text { strength in the number of } 522.45 \\
\text { Mpa. }\end{array}$ & adhesive usec & $\begin{array}{l}\text { Okechukw } \\
\text { u, 2016) }\end{array}$ \\
\hline Betel nutshell & Polyester resin, & The average hardness test in the & Different & (Aminur, \\
\hline powder & $\begin{array}{l}\text { alumina powder, and } \\
\text { mirror glaze. }\end{array}$ & $\begin{array}{l}\text { number of } 19.63 \mathrm{~kg} / \mathrm{mm}^{2} \text { and the } \\
\text { average wear rate of } 4.268 \times 10^{-6} \\
\text { gr/mm2.s }\end{array}$ & biomass used. & $\begin{array}{l}\text { Hasbi, and } \\
\text { Gunawan, } \\
\text { 2015) }\end{array}$ \\
\hline $\begin{array}{l}\text { Bamboo fiber } \\
\text { and coconut } \\
\text { shell powder }\end{array}$ & $\begin{array}{l}\text { glass powder, metal } \\
\text { powder, epoxy, } \\
\mathrm{MgO}, \mathrm{CaCO}_{3}, \mathrm{ZnO}_{2} \text {, } \\
\text { stearic acid, bakelite, } \\
\text { and sulfur. }\end{array}$ & $\begin{array}{l}\text { The largest hardness was obtained } \\
\text { with the value of } 43.4 \mathrm{~kg} / \mathrm{mm}^{2} \text {, and } \\
\text { the lowest wear rate was obtained in } \\
\text { the value of } 1.5 \times 10^{-11} \mathrm{~m}^{2} / \mathrm{N} \text {. }\end{array}$ & $\begin{array}{l}\text { Uncarbonized } \\
\text { bamboo fiber } \\
\text { and different } \\
\text { adhesive used. }\end{array}$ & $\begin{array}{l}\text { (Sutikno, } \\
\text { Sukiswo, and } \\
\text { Dany. 2012) }\end{array}$ \\
\hline $\begin{array}{l}\text { Periwinkle } \\
\text { shell }\end{array}$ & Phenolic resin & $\begin{array}{l}\text { The wear rate increases with } \\
\text { increasing the sliding speed, load, } \\
\text { temperature, and periwinkle particle } \\
\text { size. The coefficient of friction } \\
\text { obtained is within the recommended } \\
\text { standard for automobile brake pads. }\end{array}$ & $\begin{array}{l}\text { Different } \\
\text { biomass and } \\
\text { adhesive used }\end{array}$ & $\begin{array}{l}\text { (Amaren et al., } \\
\text { 2013) }\end{array}$ \\
\hline Sawdust & $\begin{array}{l}\text { Steel powder, } \\
\text { silicon carbide, } \\
\text { graphite, and epoxy } \\
\text { resin }\end{array}$ & $\begin{array}{l}\text { Sawdust of } 100-\mu \mathrm{m} \text { particle size } \\
\text { added in the brake pad allowed } \\
\text { properties that can effectively } \\
\text { replace asbestos in brake pad } \\
\text { manufacture because the properties } \\
\text { were better when samples decreased } \\
\text { in particle size. }\end{array}$ & $\begin{array}{l}\text { Different } \\
\text { biomass and } \\
\text { adhesive used }\end{array}$ & $\begin{array}{l}\text { (Lawal et al., } \\
\text { 2017) }\end{array}$ \\
\hline
\end{tabular}

\section{METHOD}

\section{Producing brake pads with bamboo fibers and dried clove leaves}

Polyester resin liquid, methyl ethyl ketone peroxide (MEKP), bamboo fibers, and clove leaves were obtained from local markets in Bandung, Indonesia. Bamboo fibers and clove leaves were put into an electrical furnace (temperature of $210^{\circ} \mathrm{C}$ for 7 hours) and saw-milled. The sawmilled products were put into sieve test (Niaga Kusuma Lestari, Indonesia) followed the ASTM D1921 standards. In the experiments, the polyester resin (191.25 g) was mixed with MEKP catalyst (19.125 g), bamboo particles, and clove leaves particles with the ratio of 
polyester/MEKP/reinforcing was fixed at 10:1:1.76. The particle size of the reinforcing components varied at 582 and $250 \mu \mathrm{m}$. Reinforcing components were mixed of components containing bamboo particles and dried clove leaves with a specific ratio (i.e. 4/1; 7/1; and 10/1). The mixture was then stirred manually and molded at room temperature and pressure for 2 days using a silicone mold with a size of $2 \times 2 \times 3 \mathrm{~cm}$.

\section{Mechanical test of bamboo fiber and dried clove leaf brake pads}

The mechanical test that is carried out is a compressive test and a puncture test. The compressive test was carried out utilizing a Screw Stand Test (Model I ALX-J, China) installed with a digital strength meter (Model HP-500, Serial No H5001909262). The compressive test is carried out by pressing the force on the brake pad, resulting a curve. The peak curve value is the maximum force pressed in Newton $(\mathrm{N})$ units used to determine the hardness of the sample. A puncture test performed using Shore Durometer Instrument (Shore A Hardness, In size, China). This test was done with a needle or probe that is inserted into the brake pad. Hardness is measured on a scale of 0 to 100 .

From the puncture test, the bulk density is calculated by equation (1):

$\rho=\frac{m}{V}$

\section{Friction test of bamboo fibers and dry clove leaves}

The friction test is done by sliding the brake pad on sandpaper ( 80 grit) for 20 minutes with a load of $8.1 \mathrm{~kg}$ at $8.3 \mathrm{~cm} / \mathrm{s}$ speed. The mass of the brake pad recorded every 2 minutes. The wear rate (M) is calculated by equation (2) (Sukrawan, Hamdani, and Mardani, 2019) :

$M=\frac{\left(M_{a}-M_{b}\right)}{t \times A}$

$\mathrm{M}_{\mathrm{a}}$ is the initial weight of the brake pad $(\mathrm{g}), \mathrm{M}_{\mathrm{b}}$ is the mass of the end of the brake pad, $\mathrm{t}$ is the test time $(\mathrm{s})$, and $\mathrm{A}$ is the area of friction $\left(\mathrm{mm}^{2}\right)$. The coefficient of friction $(\mu)$ is the ratio between the friction force (f; Newton) and the normal force (N; Newton) which is expressed in equation (3)

$\mu=f / N$

\section{RESULT AND DISCUSSION}

\section{The reaction of polyester resin}

Polymerization under room temperature and pressure were done so there is no sintering process required in this research. Figure 1 shows the first stage of the polymerization. Polyester is usually made by reacting diethylene glycol, $\mathrm{HO}-\mathrm{CH}_{2}-\mathrm{CH}_{2}-\mathrm{OH}$ and unsaturated aliphatic acid such as maleic acid, $\mathrm{HOOC}-\mathrm{CH}=\mathrm{CH}-\mathrm{COOH}$ then produce an unsaturated polyester resin 
(UPR) (Roy and James, 2002). The diethylene glycol has to give up the $\mathrm{H}$ group while the maleic acid has to give up the $\mathrm{OH}$ group and form a water molecule $\left(\mathrm{H}_{2} \mathrm{O}\right)$. An ester link forms when the carbon in the maleic acid bonds directly to the oxygen in the diethylene glycol. The process happens with hundreds or thousands of monomers to form a polyester resin chain.
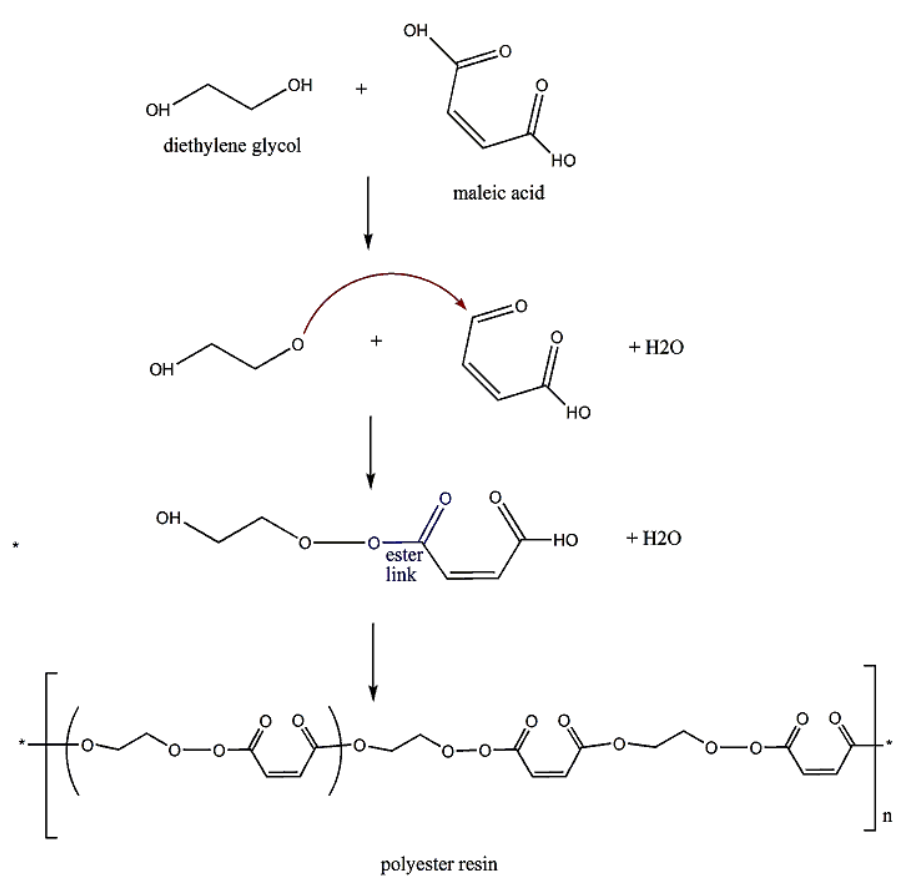

Figure 1. Synthesis of polyester resin using diethylene glycol and maleic acid.

Figure 2 shows the curing process after the addition of styrene and MEKP catalyst. The MEKP catalyst break down into free radicals that acts as an initiator that binds with the double bonds of the unsaturated polyester resin causing the unpaired electron to form. 


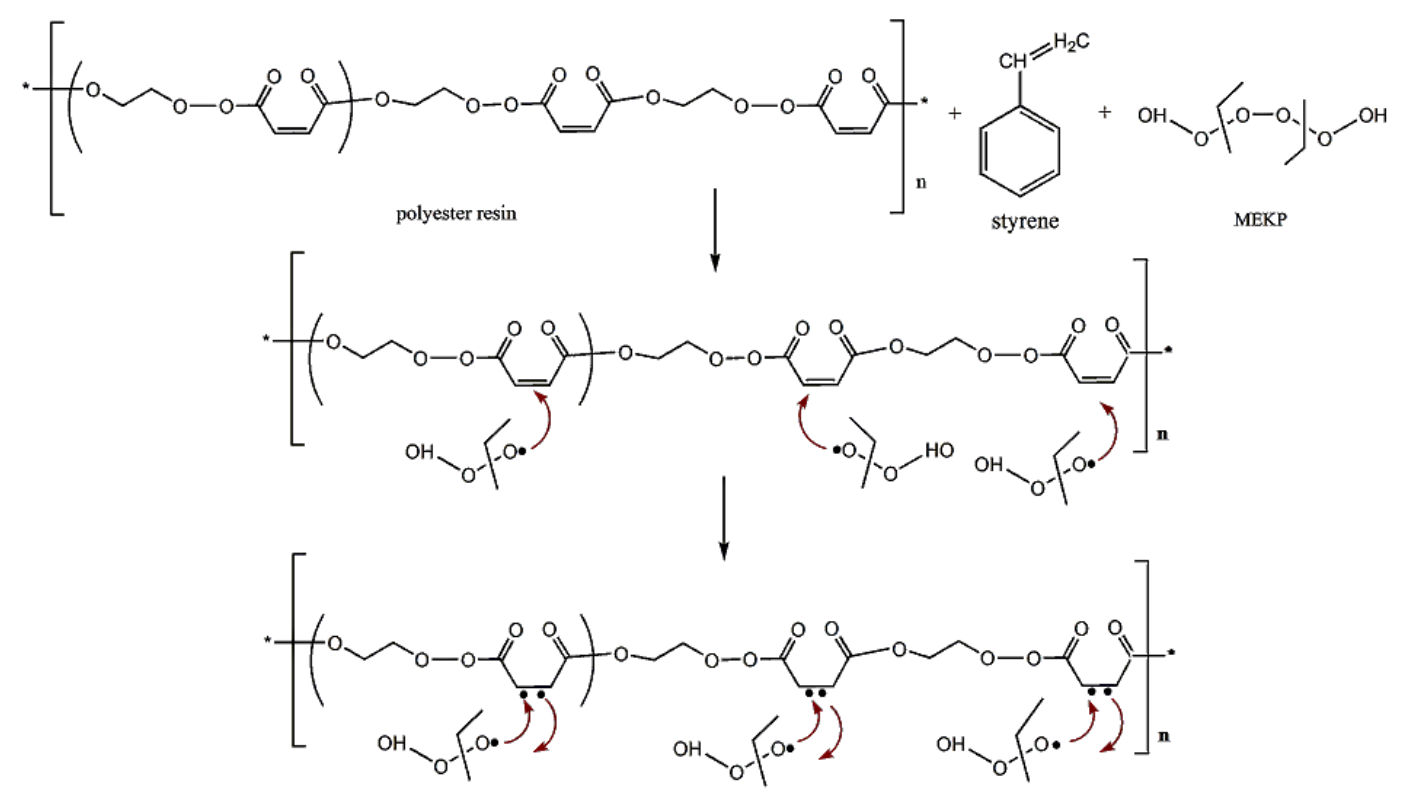

Figure 2. The reaction between polyester resin and MEKP catalyst.

Figure 3 shows the unpaired electron in the unsaturated polyester resin binds styrene molecules. The addition of styrene in up to $50 \%$ amounts reduces the viscosity of the resin and allows the resin to crosslink the chains of polyester (Loos, M. 2015). The viscosity of the resin depends on the extent of polymerization of the nolvester.

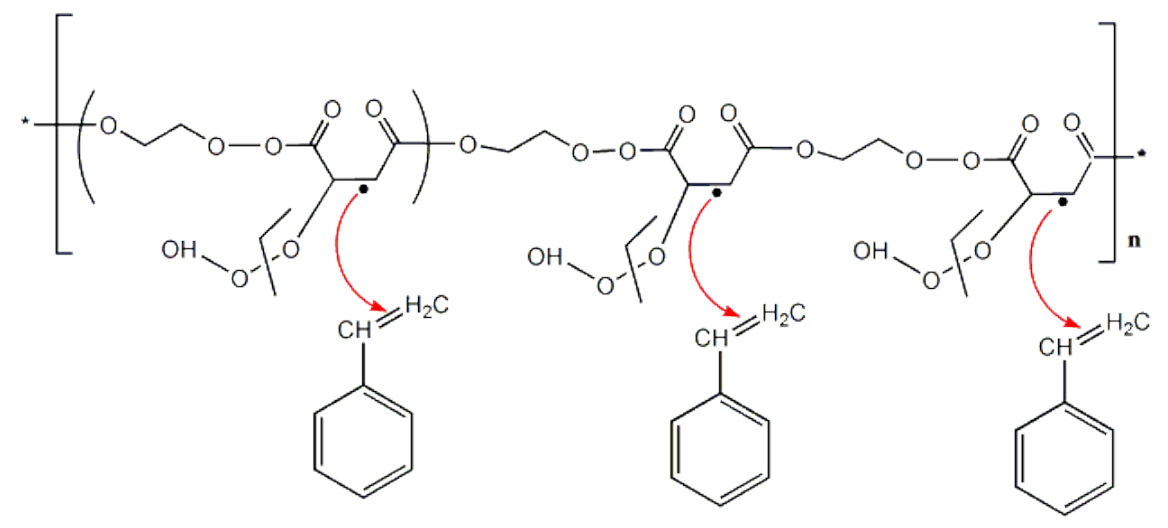

Figure 3. The formed unpaired electron attracts styrene molecules.

Figure $4 \mathrm{a}$ and $4 \mathrm{~b}$ shows the forming of a cross-link between unsaturated polyester resin with styrene by binding the unpaired electron to the double bonds on styrene. The unpaired electron in the styrene molecule and the MEKP catalyst binds to another unsaturated polyester resin molecule and form a new free radical to attack another styrene molecule to form a cross-linked structure. This reaction occurs until the unsaturated polyester resin is hardened (cured). The 
reactions are typically very slow. The reaction was exotherm mainly after the polyester resin has gelled into an intractable structure (Roy and James, 2002).

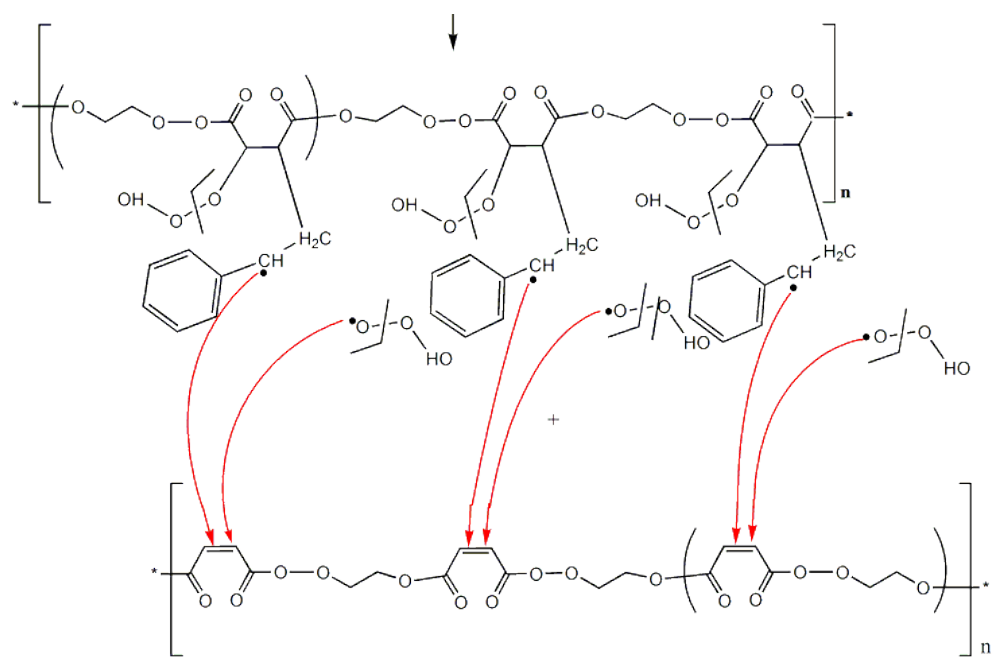

Figure 4a. The binding of unpaired electron

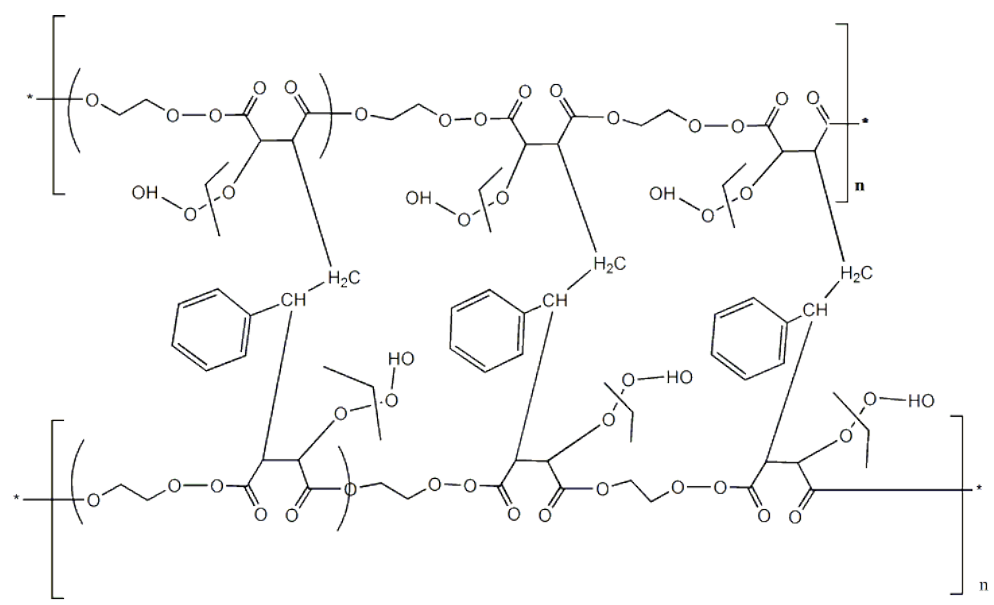

Figure 4b. Cross-link of the unsaturated polyester resin, styrene, and MEKP molecules.

\subsection{The physical form of brake pad}

Figure 5 is the image of the carbonized bamboo and dried clove leaves brake pad. The molding process allows the samples to have a cube shape with $2 \times 2 \mathrm{~cm}$ surface size and the height was between 1.4 and $2 \mathrm{~cm}$. As seen in figure 5, the surface of the brake pads with a size of $584 \mu \mathrm{m}$ were rough, the particles were bigger and not uniformly distributed than the $250 \mu \mathrm{m}$ brake pad. 


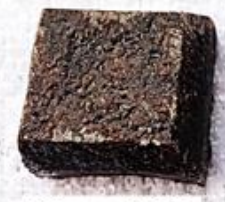

$584 \mu \mathrm{m}$, ratio $4 / 1$

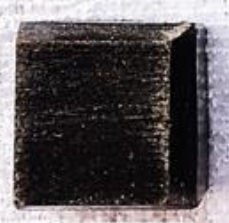

$250 \mu \mathrm{m}$, ratio $4 / 1$
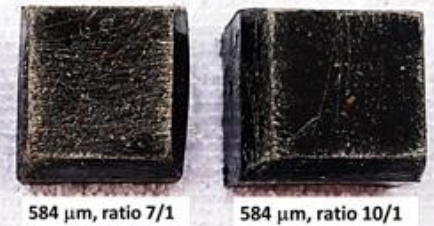

$584 \mu \mathrm{m}$, ratio $10 / 1$

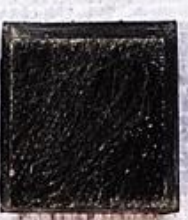

$250 \mu \mathrm{m}$, ratio $7 / 1$

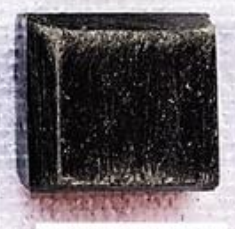

$250 \mu \mathrm{m}$, ratio $10 / 1$

Figure 5. Carbonized bamboo fiber and dry clove leave brake pad.

Table 2 shows the microscope images with a 1-mm scale of the brake pad's surface. As shown in Table 2, the carbonized bamboo fiber and dried clove leaves in the brake pad sample with $582 \mu \mathrm{m}$ particle size were bigger and not evenly distributed compared with the brake pad sample with $250 \mu \mathrm{m}$ and the sample with $582 \mu \mathrm{m}$ has more pores than the $250 \mu \mathrm{m}$ size. Different porosities were obtained, in which the larger particles allowed the appearance of more pores (Aigbodon et al., 2010). Changes in element weight in the composition of the material can affect the quality, chemical, mechanical and physical properties of brake pads (Abutu et al. 2018) (Bagaskara, Widodo, and Pramono, 2019).

Table 2. Brake pad surface with $1 \mathrm{~mm}$ scale of carbonized bamboo fibers and carbonized dried clove leaves.

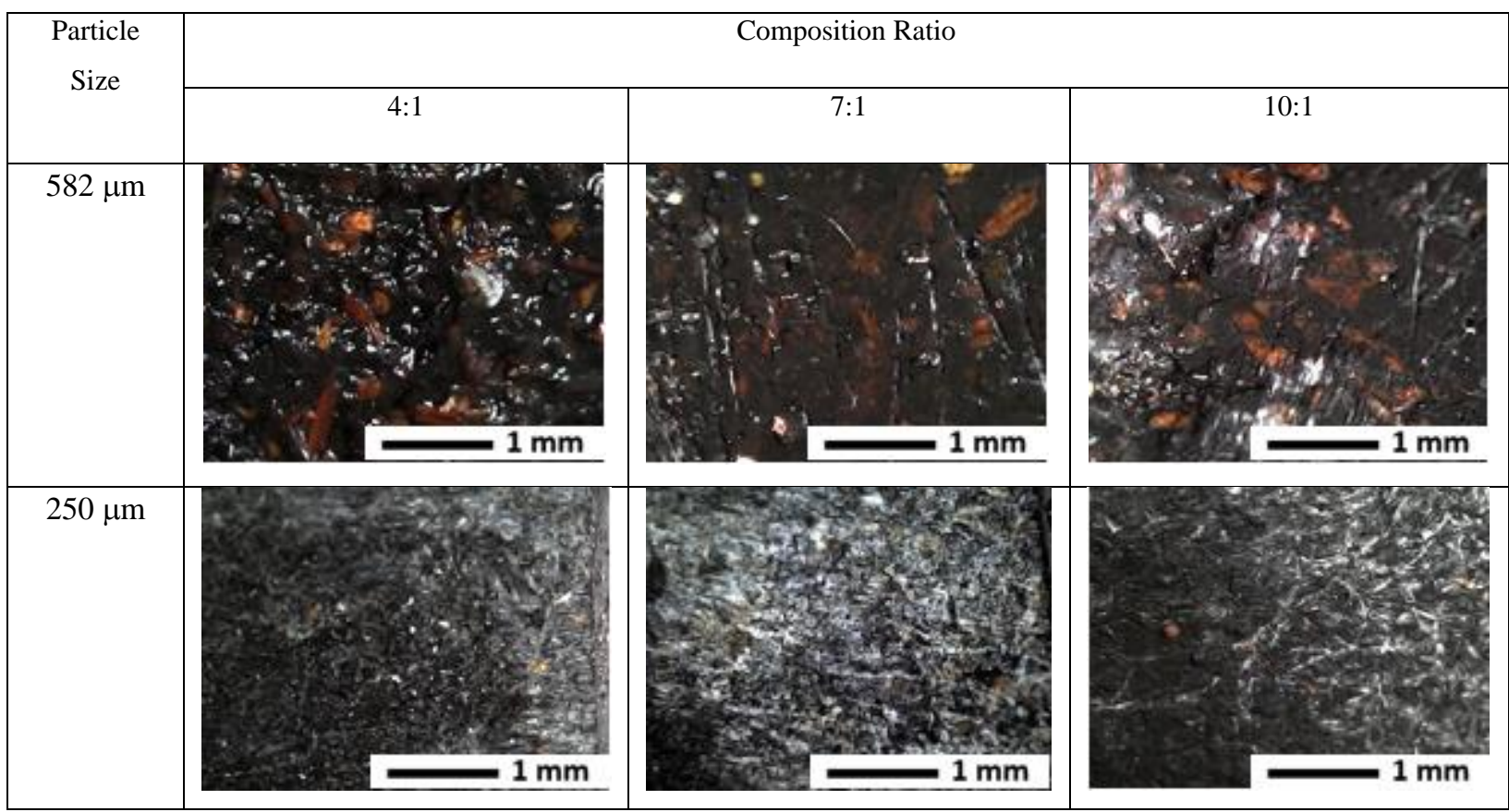




\section{Mechanical properties of bamboo fibers and dried clove leaves brake pad}

Figure 7 shows the compressive strength of the brake pad. Figure 7 shows that the smaller the particle size, the higher the hardness value, and the larger amount of carbonized bamboo shows the larger hardness value. It can be seen that the particle size of $250 \mu \mathrm{m}$ with a ratio of carbonized bamboo fibers and carbonized dried clove leaves is 10/1 has the largest than the rest of the brake pad sample. It requires $23.4323 \mathrm{~N} / \mathrm{mm}^{2}$ compressive force. This happens because as the carbonized bamboo and dried clove leaves size increases; there is an increase in interfacial area, this increase in interfacial area results in poor interfacial bonding and inefficient stress transfer between particles and the resin (Sasaki, 1995). The compressive strength of the brake pad sample is needed to be able to accept the load press (Agustinus and Wayan, 2013) during the braking process.

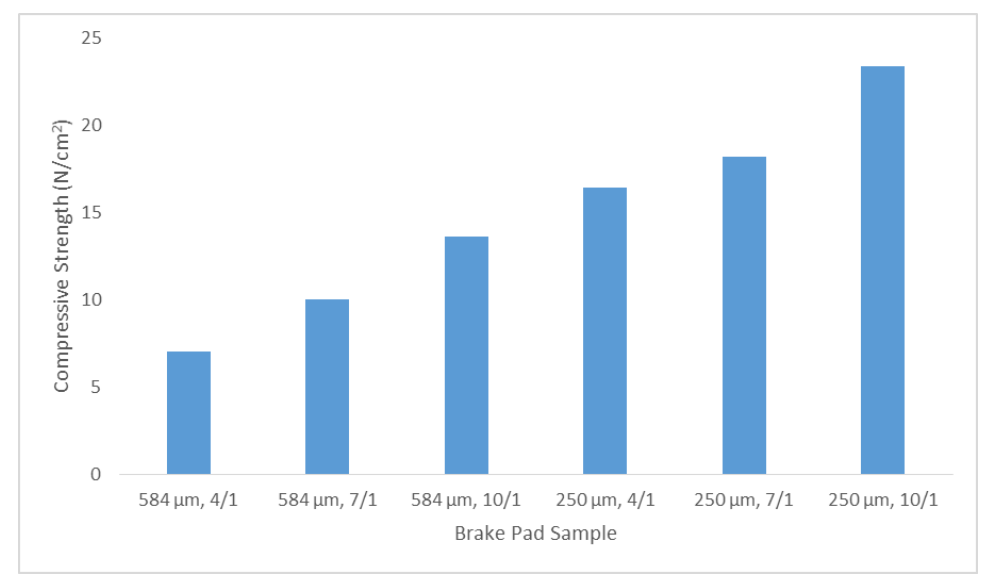

Figure 6. The compressive strength on carbonized bamboo fiber and dried clove leaves brake pad.

Table 3 shows the results of the puncture test, porosity value, and the bulk density of carbonized bamboo fiber and dry clove leaves brake pad. The biggest puncture test value also obtained by the particle size of $250 \mu \mathrm{m}$ with a ratio of carbonized bamboo fibers and dry clove leaves $10 / 1$ in the number of 96 . The greater the puncture test value, the harder the brake pads sample so that the value is directly proportional. Durometer hardness measurements assess the material resistance to indentation (Qi, Joyce, and Boyce, 2002). The porosity shows that the smaller the particle size, the smaller pore volume so the value is proportional. The smallest 
porosity value obtained in $250-\mu \mathrm{m}$ particle size with the 10:1 composition ratio in the value of $0.0213 \mathrm{~cm}^{3}$. The compressive test, puncture test, and porosity test results showed good value in smaller particle size because the small particle size can be more uniformly distributed, and space in the brake pad gets narrower and denser due to the good bonding between the composites and the resin and the closer inter-packing distance as the particle size decreases. The graph that decreases gradually as the particle size gets bigger also caused by the smaller surface area and the pore capability of the bamboo and clove leaf particles in the resin (Aigbodon et al., 2010). Large particle size can trap air during the mixing process causing pores, and increased the crack path and stress intensity which makes brake pads susceptible to pressure and indentation (Rezanezhad et al, 2019). The more bamboo composition in brake pads, the greater force required to press the brake pads to shred. This occurs because the carbonized bamboo has better mechanical properties than bamboo without treatment due to the increased crystallinity of bamboo fibers and increasing the polarity of the molecule, the binding force of the molecule is relatively small so the elongation during impact decreases and the tensile strength and elastic modulus increased (Ma et al., 2012). When the particle density smaller, the brake pad density smaller (Aigbodon et al.,

2010), and the compressive value is getting bigger. The largest sample density value of carbonized bamboo and dried clove leaves brake pad on is in the value of $1.7618 \mathrm{~g} / \mathrm{cm}^{3}$ at 582 $\mu \mathrm{m}$ particle size and ratio $4 / 1$, inversed with the hardness value. This occurs because the bulk density is affected by many factors, such as volume weight and bulk specific gravity (Black and Blake, 1965).

Table 3. Puncture test, pore size, and bulk density of brake pad.

\begin{tabular}{|c|c|c|c|c|}
\hline $\begin{array}{c}\text { Particle } \\
\text { size }\end{array}$ & Composition & Porosity $\left(\mathrm{cm}^{3}\right)$ & Durometer Shore Hardness Scale & Bulk Density $\left(\mathrm{g} / \mathrm{cm}^{3}\right)$ \\
\hline $582 \mu \mathrm{m}$ & $4 / 1$ & 0.0735 & 70.75 & 1.7618 \\
\hline & $7 / 1$ & 0.0382 & 82.875 & 1.6719 \\
\hline & $10 / 1$ & 0.0285 & 84 & 1.2277 \\
\hline $250 \mu \mathrm{m}$ & $4 / 1$ & 0.0254 & 85.375 & 1.3293 \\
\hline & $7 / 1$ & 0.0252 & 88.75 & 1.3761 \\
\hline & $10 / 1$ & 0.0213 & 96 & 1.3262 \\
\hline
\end{tabular}

\section{Friction properties of bamboo fibers and dried clove leaves brake pad}

The frictional force is the force in the opposite direction to other objects that touch each other or the direction of the object's tendency to move (Nandiyanto et al., 2019). The characteristics of friction and wear have an important role in finding out which new formulations are right for 
the brake system for a particular vehicle (Sumiyanto, Abdunnaser, and Fajri, 2019) depends on several factors such as pressure, velocity, interface temperature, the composition of the friction material, duration and length of the friction path, the density of the friction material, modulus of elasticity, type, design, and geometry of the friction mechanism (Bretotean et al, 2018).

Figure 8 is a graph of the mass lost during the friction test and Table 5 is the value of the massloss rate, wear rate, and the coefficient of friction for the brake pad sample. As seen in figure 8, the brake pad sample with a particle size of $250 \mu \mathrm{m}$ with a composition of $7 / 1$ has the lowest mass loss rate value and the mass-loss rate value in Table 5 is $0.1225 \mathrm{~g} / \mathrm{min}$.

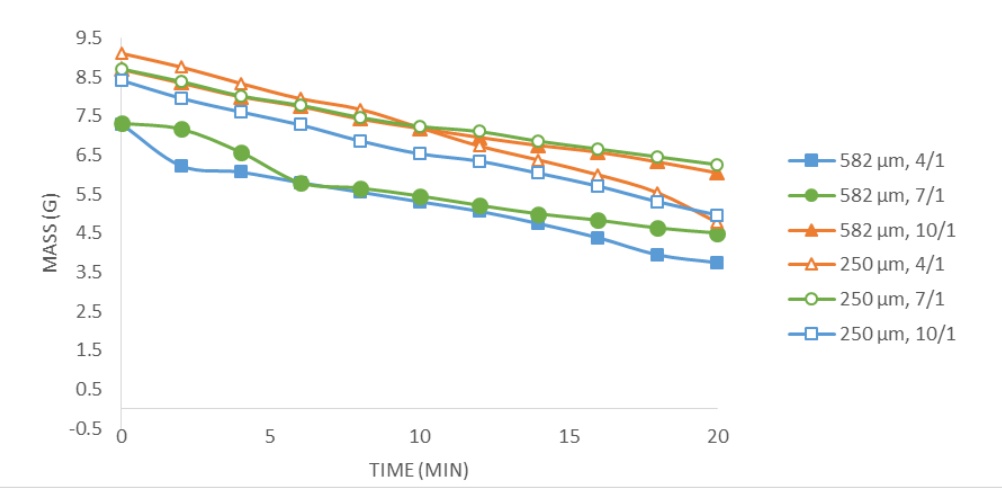

Figure 8. graph of bamboo fiber and dried clove leaves brake pad mass loss.

From Table 4, it can be seen that the lowest wear rate is obtained at a particle size of $250 \mu \mathrm{m}$ with a composition of $4 / 1$ in the number of $1.08 \times 10-6 \mathrm{~g} / \mathrm{s} . \mathrm{mm}^{2}$. The wear rate is the progressive loss of material or the removal of some materials from the movement of one surface to another (Sumiyanto et al. 2019). This is inversely proportional to the results of the compressive test, namely the tougher mater is, the smaller the value of its wear rate is because the better its microstructure (Kristianta et al, 2017). Also smaller particles have higher total surface energy for a given particle loading. Wear decreases with increasing surface area of the particles through a more efficient stress transfer mechanism (Mohanty and Chugh, 2007). The highest friction coefficient was also obtained in samples with a particle size of $250 \mu \mathrm{m}$ with a composition of 4/1 with 0.1108 value. The lower the carbonized bamboo and dried clove leaves particle size, the higher is the friction coefficient (Amaren et al. 2013). This happens due to the formation of the layer formed underneath the surface friction area during the initial stage of wear which contributes toward overcoming the roughness of machine marks on the samples. Once this layer reaches some critical thickness, dynamic competition between material transfer processes (Keon et al. 2008) (Byme and Wang, 2001). The friction between the disc and the canvas results in heat dissipation due to the change in kinetic energy into thermal energy (Agung, 2008). Changes in temperature due to heat dissipation generally cause 
changes in the coefficient of friction. The higher the temperature, the lower the friction coefficient (Bhyrav, 2006). From the results of the wear rate and friction coefficient, it can be concluded that the smaller the particle size the better the wear rate and friction coefficient, and the best composition for the wear rate and friction coefficient is $4 / 1$.

Table 4. Mass loss rate, wear rate, and friction coefficient value on bamboo fiber and dried clove leaves brake pad sample. Where $M_{a}$ is the initial weight of the brake pad, $M_{b}$ is the mass of the end of the brake pad, $\mathrm{t}$ is the test time, $\mathrm{A}$ is the area of friction, and $\mathrm{M}$ is the wear rate of the brake pad.

\begin{tabular}{|c|c|c|c|c|c|c|c|c|}
\hline $\begin{array}{c}\text { Particle } \\
\text { Size }\end{array}$ & $\begin{array}{c}\text { Compos } \\
\text { ition }\end{array}$ & $M_{a}(\mathrm{~g})$ & $M_{b}(\mathrm{~g})$ & $\begin{array}{c}\text { Mass loss rate } \\
(\mathrm{g} / \mathrm{min})\end{array}$ & $t(\mathrm{~s})$ & $\begin{array}{c}A \\
\left(\mathrm{~cm}^{2}\right)\end{array}$ & $\begin{array}{c}\text { Wear rate/M } \\
\left(\mathrm{g} / \mathrm{s} . \mathrm{mm}^{2}\right)\left(\times 10^{-6}\right)\end{array}$ & $\begin{array}{c}\text { Friction } \\
\text { coefficient }\end{array}$ \\
\hline $582 \mu \mathrm{m}$ & $4 / 1$ & 7.3 & 3.75 & $0.1775 \pm 0.2638$ & 1200 & 3.23 & 7.03 & 0.1066 \\
\hline & $7 / 1$ & 7.32 & 4.51 & $0.1405 \pm 0.2204$ & 1200 & 3.33 & 9.16 & 0.1096 \\
\hline & $10 / 1$ & 8.7 & 6.05 & $0.1325 \pm 0.0596$ & 1200 & 3.06 & 7.21 & 0.0689 \\
\hline $250 \mu \mathrm{m}$ & $4 / 1$ & 9.11 & 4.78 & $0.2165 \pm 0.1308$ & 1200 & 3.325 & 1.08 & 0.1108 \\
\hline & $7 / 1$ & 8.71 & 6.26 & $0.1225 \pm 0.0707$ & 1200 & 3.42 & 5.97 & 0.0700 \\
\hline & $10 / 1$ & 8.42 & 4.97 & $0.1725 \pm 0.0718$ & 1200 & 3.42 & 8.4 & 0.0380 \\
\hline
\end{tabular}

Table 5 shows the comparisons between the conventional brake pad and carbonized bamboo and dried clove leaves brake pad with the lowest value of the wear rate and the highest coefficient of friction, namely samples with a particle size of $250 \mu \mathrm{m}$ with a composition of $4 / 1$. The wear rate on carbonized bamboo and dried clove leaves-based brake pads has a lower value than conventional brake pads, so they are less prone to wear. Meanwhile, the value of the friction coefficient on carbonized bamboo and dried clove leaves brake pad was smaller with a difference of $10 \%$. So that carbonized bamboo and dry clove leaves brake pad with a particle size of $250 \mu \mathrm{m}$ and the composition of carbonized bamboo/dried clove leaves with the ratio of 4/1 can still be used for brake pad applications.

Table 5. The comparison of the developed carbonized bamboo and dried clove leaves brake pad and conventional brake pad. Where $\mathrm{M}_{\mathrm{a}}$ is the initial weight of the brake pad, $\mathrm{M}_{\mathrm{b}}$ is the mass of the end of the brake pad, $t$ is the test time, $\mathrm{A}$ is the area of friction, and $\mathrm{M}$ is the wear rate of the brake pad.

\begin{tabular}{|l|l|l|l|l|l|l|l|}
\hline Sample & $\mathrm{M}_{\mathrm{a}}(\mathrm{g})$ & $\mathrm{M}_{\mathrm{b}}(\mathrm{g})$ & $\begin{array}{l}\text { Mass loss rate } \\
(\mathrm{g} / \mathrm{min})\end{array}$ & $\mathrm{t}(\mathrm{s})$ & $\mathrm{A}\left(\mathrm{mm}^{2}\right)$ & $\begin{array}{l}\mathrm{M}\left(\times 10^{-6}\right. \\
\left.\mathrm{g} / \mathrm{s} . \mathrm{mm}^{2}\right)\end{array}$ & $\begin{array}{l}\text { Friction } \\
\text { coefficient }\end{array}$ \\
\hline $250 \mu \mathrm{m}-104 \mu \mathrm{m}, 80 \%: 20 \%$. & 9.11 & 2.39 & $0.108 \pm 0.131$ & 60 & 33 & 1.08 & 0.1108 \\
\hline Conventional brake pad & 1.555 & 0.187 & $0.076 \pm 0.067$ & 60 & 85 & 1.68 & 0.2099 \\
\hline
\end{tabular}




\section{CONCLUSION}

The effect of particle size and composite composition of bamboo powder and dry clove leaves on brake pad application with polyester resin adhesive has been investigated. The test results showed that the smaller the particle size $(250 \mu \mathrm{m})$ has the better the mechanical properties. However, the $250 \mu \mathrm{m}$ particle size with a ratio of 10/1 shows good results on the hardness with a value of $23.8343 \mathrm{~N} / \mathrm{cm}^{2}$ and porosity with $0.0213 \mathrm{~cm}^{3}$ pore volume, the ratio of $7 / 1$ shows good results on the weight loss of mass, with the value of the mass-loss rate $0.1225 \mathrm{~g} / \mathrm{min}$, while the 4/1 composition ratio has the largest coefficient of friction with a value of 0.1108 and the lowest wear rate of $1.08 \mathrm{~g} / \mathrm{s} . \mathrm{mm}^{2}$. Overall, carbonized bamboo powder and dry clove leaves as a reinforcement material can be used for brake pad applications with the comparison between the carbonized bamboo and dried clove leaves brake pad and the conventional brake pad has better wear rate and only $10 \%$ difference smaller in friction coefficient value.

\section{REFERENCES}

Abutu, J., Lawal, S.A., Ndaliman, M.B., and Lafia Araga, R.A. 2018. An Overview of Brake Pad Production Using Non-Hazardous Reinforcement Materials. Aca Technica Corviniensis - Bulletin of Engineering 9(3).

Agustinus, P.I. and I Wayan, S. 2013. Kekuatan tekan dan flexural material komposit serat bambu epoksi. Jurnal Teknik Mesin 24(2): 59-63.

Aigbodion, V.S., Akadike, U., Hassan, S.B., Asuke, F., and Agunsoye, J.O. 2010. Development of Asbestos - Free Brake Pad Using Bagasse. Tribology in Industry 32(1): 12-18.

Amaren, S. G., Yawas, D. S., and Aku, S. Y. 2013. Effect of periwinkles shell particle size on the wear behavior of asbestos free brake pad. Results in Physics 3: 109-114.

Aminur, H. M. and Gunawan, Y. 2015. Proses Pembuatan Biokomposit Polimer Serat untuk Aplikasi Kampas Rem. Seminar Nasional Sains dan Teknologi. ISSN 2407 - 1846.

Bagaskara, A., Widodo S., and Pramono C. 2019. Pengaruh Serbuk Kulit Biji Mangga sebagai Penguat Komposit Kampas Rem terhadap Sifat Mekanis. Jurnal Teknik Mesin MERC (Mechanical Engineering Research Collection) 2(2).

Bhyrav, M. 2006. Thermal Conductivity Characterization of Composite Materials. Thesis Departement of Mechanical Engineering Mthiorgantown, West Virginia, USA.

Black, C. A., and Blake, G. R. 1965. Bulk Density Agronomy Monograph. Scientific journal series, minnesota agr. Exp. Sta 4433: 374-388.

Christopher, B., and Zhiyuan, W. 2001. Influence of thermal properties on friction performance of carbon composites. J Wear 39(12): 1789-801.

Crawford, R. J. and Throne, J. L. 2002. ROTATIONAL MOLDING POLYMERS. Rotational Molding Technology: 19-68.

Da Costa, L.L., Loiola, R.L., and Monteiro, S.N. 2010. Diameter dependence of tensile strength by Weibull analysis: Part I bamboo fiber 15(2): 110-116.

Dwivedi, U.K., Ghost, A. and Chan, N. 2009. Role of PVA Modification in Improving the Sliding Wear Behaviour of Bamboo. BioResources 4(2): 522-528. 
Jirovetz, L., Buchbauer, G., Stoilova, I., Stoyanova, A., Krastanov, A., and Schmidt, E. 2006. Chemical Composition and Antioxidant Properties of Clove Leaf Essential Oil. Journal of Agricultural and Food Chemistry 54(17): 6303-6307.

Keon, H.C., Min, H.C., Seong, J,K., and Ho, J. 2008. Tribological properties of potassium titanate in the brake friction material; morphological effects. J Tribol 32(1): 59-66.

Kristianta, F.X., Kristian, I.T.A., and Sholahuddin, I. 2017. Variasi Ukuran terhadap Kekerasan dan Laju Keausan Komposit Epoxy Aluminium-Serbuk Tempurung Kelapa untuk Kamps Rem, Jurnal Rekayasa Mesin 8(3): 149-153.

Kumar, S., Choudhary, V. and Kumar, R. 2010. Study on the compatibility of unbleached and bleached bamboo-fiber with LLDPE matrix. J. Therm Anal Calorim 102: 751-761.

Lawal, S.S., Bala, K.C., and Alegbede, A. T. 2017. Development and production of brake pad from sawdust composite. Leonardo Journal of Sciences 30 : 47-56. ISSN 1583-0233.

Li, S.H., Wijn, D., Groot, D., Zeng, Q.Y., and Zhou, B.L. 1998. Reformed bamboo/glass fabric/aluminium composite as an ecomaterial. Journal of Materials Science 33: 2147-2152.

Loos, M. (2015). Composites. Carbon Nanotube Reinforced Composites, 37-72.

Ma, Y., Shen, S., Tong, J., Ye, W., Yang, Y., and Zhou, J. 2012. Effects of Bamboo Fibers on Friction Performance of Friction Materials. Journal of Thermoplastic Composite Materials 26(6): 845859.

Mohanty, S. and Chugh, Y.P. 2007. Development of fly ash - based automotive brake lining. J. Tribol. Int. 40(7): 1217-24.

Nandiyanto, A.B.D., Triawan, F., Firly, R., Abdullah, A.G., Aono, Y., Inaba, K., and Kishimoto, K. 2019. Identification of micro-mechanical characteristics of monoclinic tungsten trioxide microparticles by nanoindentation technique. Materials Physics and Mechanics 42 (3): 323-329.

Olabisi, A, I., Adam, A.N., and Okechukwu, O, M. 2016. Development and Assessment of Composite Brake Pad Using Pulverized Cocoa Beans Shells Filler. International Journal of Materials Science and Applications 5(2), 66-78.

Pinca-Bretotean C., Josan, A., and Băneasă, C.B. 2018. Laboratory testing of brake pads made of organic materials intended for small and medium vehicles. IOP Conference Series Materials Science and Engineering 393(1): 1-7.

Puja, I.G.K. 2010. Studi sifat impak ketahanan aus dan koefisien gesek bahan komposit arang limbah serbuk gergaji kayu glugu dengan matrik epoxy. Jurnal Ilmiah Teknik Mesin CakraM 4(2) : 155-159.

Qi, H.J., Joyce, K., and Boyce, M.C. 2002. Durometer hardness and the stress-strain behavior of elastomeric materials 76: 419-435.

Rezanezhad, M., Lajevardi, S. A., and Karimpouli, S. 2019. Effects of pore-crack relative location on crack propagation in porous media using XFEM method. Theoretical and Applied Fracture Mechanics 103: 102-241.

Sasaki, Y. 1995. Development Philosophy of Friction Materials for Automobile Disc Brakes. The Eight International Pacific Conference on Automobile Engineering. Society of Automobile Engineers of Japan; Society of Automobile Engineer of Japan: 407-412.

Suarya, P. 2007. Adsorpsi Pengotor Minyak Daun Cengkeh oleh Lempung Teraktivasi Asam. Jurnal Kimia 2(1): 19-24. 
Suhardjo, K. A., Syampurwadi, A., Sebleku, P., and Karina, M. 2013. Application of rice straw lignin-based carbon fiber for bus/truck's asbestos-free composite break line. Jurnal Riset Industri 7(3) : 183-190.

Sukrawan, Y., Hamdani, A., and Mardani, S.A. 2019. Effect of Bamboo Weight Faction on Mechanical Properties in Non-Asbestos Composite of Motorcycle Brake Pad. Materials Physics and Mechanics 42: 367-372.

Sumiyanto, A., and Fajri, A.N. 2019. Analisa Pengujian Gesek, Aus dan Lentur pada Kampas Rem Tromol Sepeda Motor. Bina Teknika 15(1): 49-59.

Suryadi, A. 2008. Fabrikasi Rem Komposit Made In Indonesia.Program Studi Ilmu Material Universitas Indonesia.

Sutikno, S.E,. Sukiswo, and Dany, S.S. 2012. Sifat mekanik bahan gesek rem komposit diperkuat serat bambu. Jurnal Pendidikan Fisika Indonesia 8 : 83-89. ISSN: 1693-1246.

Tagora, B. P. S. and Rinaldry, S.I. 2012. Penentuan Kondisi Keseimbangan Unit Leaching pada Produksi Eugenol dari Daun Cengkeh. Jurnal Teknik Kimia USU 1(1): 10-14.

Thwe, M.M. and Liao, K. 2003. Environmental effects on bamboo-glass/ polypropylene hybrid composites. Journal of Materials Science 38: 363-376. 